\title{
CHILDREN'S AGE WHEN GETTING COMPLEMENTARY FOOD AND SHORT STATURE EVENTS IN CHILDREN 12-24 MONTHS
}

\author{
Adisti Kristianingrum ${ }^{1)}$, Lisa Pangemanan'), Ika Christine ${ }^{3)}$
}

\begin{abstract}
Introduction: Short stature remains a nutritional problem in Indonesia. World Health Organization (WHO) data showed that Indonesia is the third-highest ranked for short stature prevalence among countries in Southeast Asia. National Basic Health Research (Riskesdas) in 2013 stated that the prevalence of short stature children was $37.2 \%$. Short stature is caused by various factors, and one of the causes is early complementary feeding.

Purpose: To analyze the association between child age when receiving complementary feeding and short stature in children 12-24 months.

Method: This research was an observational analytic study with a cross-sectional design. Sampling technique using non-probability sampling, i.e., consecutive sampling. Data collected through interviews, questionnaires, and physical examinations of children's body length and weight. Research location was in the working area of the Sidorejo Community Health Center. Statistical analysis using Chi-square test. There were 182 subjects included in this study. Results: Among those who received complementary feeding before six months old, 53 children $(76.8 \%)$ had short stature, and 16 children $(23.2 \%)$ were normal. Meanwhile, after six months old, those who received complementary feeding were 40 children $(35.4 \%)$ who had short stature, and 73 babies $(64.4 \%)$ received complementary foods after six months with normal growth. Chi-square test showed a significant association between child age when receiving complementary feeding and short stature among children aged 12-24 months in the working area of the Sidorejo Community Health Center ( $<<0,001$; PR $=2.17,95 \% \mathrm{CI}=1.64-$ 2.87). Conclusion: There is a significant relationship between child age when receiving complementary feeding and short stature in the working area of the Sidorejo Community Health Center.
\end{abstract}

Keyword: complementary foods, short stature, children aged 12-24 months.

\footnotetext{
${ }^{1)}$ Student of Faculty of Medicine, Widya Mandala Surabaya Catholic University Indonesia, J1. Kalisari Selatan No.1 Surabaya Email: adistikristianingrum85@gmail.com

${ }^{2)}$ Pediatric Department, Faculty of Medicine, Widya Mandala Surabaya Catholic University Indonesia, Jl. Kalisari Selatan No.1 Surabaya

${ }^{3)}$ Internal Medicine Department, Faculty of Medicine, Widya Mandala Surabaya Catholic University Indonesia, Jl. Kalisari Selatan No.1 Surabaya
} 


\section{INTRODUCTION}

Short stature is one of the malnutrition problems experienced by Indonesian children. According to the Indonesian According to Pediatrician Association (IDAI), short stature is a terminology for a child's height that is less than the 3rd percentile or -2 Standard Deviation (SD) according to age and sex on the growth curve that applies to the population. ${ }^{1}$ Definition of short stature according to World Health Organization (WHO) is based on the Body Length/Age index or Height/Age which is in the anthropometric standard for assessing children's nutritional status, the measurement results are in the Z-score threshold <- $2 \mathrm{SD}$ to $-3 \mathrm{SD}$ (short/stunted) and <-3 SD (very short or severely stunted). ${ }^{2}$

Based on Nutrition Status Monitoring data for the past three years, the incidence of short stature has the highest prevalence than other nutritional problems such as thinness with a prevalence rate of $17.7 \%$ and fatness with a prevalence rate of $8 \%{ }^{3}$ The prevalence of short stature children according to WHO, Indonesia ranks third with the highest prevalence in the Southeast Asia/South-East Regional Asia. ${ }^{4}$ Basic Health Research (Riskesdas) 2013 in Indonesia recorded that short stature still counts as severe health problem, with a national prevalence of $37.2 \%$. This figure is higher than in 2010, which was $35.6 \%$, and in 2007 it was $36.8 \%$. Under the age of five years (toddlers), the prevalence of short stature was $37.2 \%$, age 5-12 years was $30.7 \%$, ages $13-15$ years was $35.1 \%$, and ages 16-18 years was $31.4 \%{ }^{5}$ The prevalence of short stature obtained from the Ministry of Health of the Republic of Indonesia (Kemenkes RI) in 2016 was $38.9 \%{ }^{6}$ Similarly, the prevalence for short stature in East Java in 2018 was $29.9 \%{ }^{7}$

The short stature prevalence that is still high indicate that the nutritional problems in Indonesia are chronic, concerning the limited economy, low education, inadequate services, and environmental health. Nutrition problems related to various aspects are directly affected by infectious diseases and nutritional intake that lacks quality and quantity, while indirectly affected by the reach and quality of health services, inadequate child care, environmental sanitation, and low food security at the household level. ${ }^{8}$

The first six months of life are sufficient to meet nutritional needs. Breastfeeding alone is not enough when children are aged 6-24 months. Additional supplementary breast milk is needed (complementary foods). Complementary foods must be given in stages, both in form and amount according to the child's age. When start giving complementary foods, the mismatch increases risks $2.8-4.2$ times to become short stature. Children who are 
12 months old need to receive food like adults but in smaller portions. This is because milk production at the age of 12 months has begun to decrease. In addition, the digestive system in children aged 12 months is relatively complete. ${ }^{9-12}$

Children with short stature categories obtained from data from the Sidorejo Community Health Center in 2018 are known to still have a relatively high incidence, 402 children out of 2,095 total children under five, and become one of the particular locations reviewed by the Kediri Health Office. Based on the background above, we are interested in researching the association of age of children when getting complementary foods and short stature incidences in the age range of 12-24 months and the study were conducted in the working area of the Sidorejo Community Health Center, Pare District, Kediri Regency. This research is expected to provide further data and nutritional proposals in child growth and development, especially in Kediri Regency.

\section{METHOD}

This research is an observational analytic study with a cross-sectional design. The population in this study were all children aged 12-24 months in the working area of the Sidorejo Community Health Center, Pare Subdistrict, Kediri
Regency during July-August 2019. The sample in this study was all children aged 12-24 months in the working area of the Sidorejo Community Health Center during July-August 2019 who met the inclusion and exclusion criteria.

Sampling was done by non-probability sampling technique, namely consecutive sampling. Every subject in the working area of the Sidorejo Community Health Center that fulfilled the inclusion and exclusion criteria were included in the study until the number of subjects was complete.

The inclusion criteria of this study were children aged 12-24 months, children receiving complementary foods, willing to be sampled, complete baseline data. In contrast, exclusion criteria were congenital abnormalities such as congenital heart disease and congenital kidney disease and genetic disorders such as Down syndrome.

The procedure of this study was that parents of children who met the inclusion criteria were interviewed following the questions that have been prepared. Then we did a physical examination related to short stature by measuring the child's body length using an infantometer and classifying the child's body length by age into anthropometry according to WHO 2018. 


\section{RESULTS}

\section{Table 1. Basic Characteristics of Parents and Children $(n=182)$}

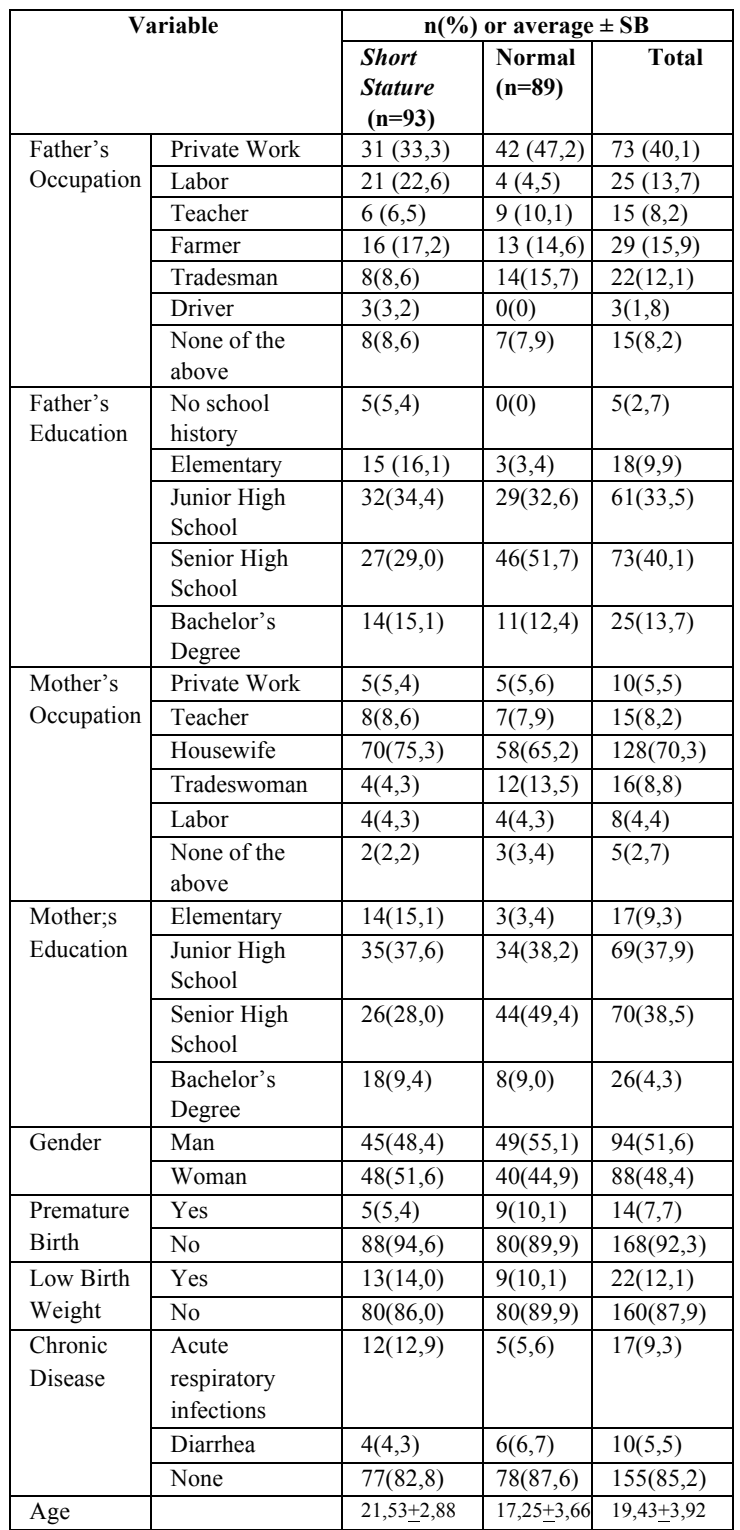

Table 1 shows the characteristics of respondents based on the father's occupation for the highest percentage of short stature children of 31 people (33.4\%) working as private companies. Characteristics of fathers with short stature children based on the level of education as many as 32 people (34.4\%) with the latest education at junior high school level. Most mothers with short stature children work as housewives, namely 70 mothers $(75.3 \%)$. Characteristics of respondent mothers in short stature children based on the level of education as many as 35 people $(37.6 \%)$ were educated at the junior high school level. Based on the incidence of short stature by gender, most were female, as many as $49(55.1 \%)$ children. Whereas in boys there were $45(48.4 \%)$. Most of the children were short-term non-premature children,88 (94.6\%) children. More shortstature children were born with an average weight equal to $80(86.0 \%)$ based on the history of birth weight. Short stature children with a history of diarrhea infection amounted to 4 people $(4.3 \%)$, while short stature children with a history of ARI were $12(12.9 \%)$. The children in this study were aged 12 to 24 months with a mean age of $19.43+3.92$ months. 
Table 2. Characteristics of complementary feeding for children aged 12-24 months in the Sidorejo Community Health Center, 2019 $(n=182)$

\begin{tabular}{|c|c|c|c|c|}
\hline \multirow[t]{2}{*}{ Variable } & & \multicolumn{2}{|c|}{$\mathrm{n}(\%)$ or average $\pm \mathrm{SB}$} & \multirow[t]{2}{*}{ Total } \\
\hline & & $\begin{array}{l}\text { Short } \\
\text { Stature } \\
(\mathrm{n}=93)\end{array}$ & $\begin{array}{l}\text { Normal } \\
(n=89)\end{array}$ & \\
\hline \multirow{2}{*}{$\begin{array}{l}\text { Breastmilk } \\
\text { substitute } \\
\text { foods }\end{array}$} & Yes & $78(83,9)$ & $81(91,0)$ & $159(87,4)$ \\
\hline & No & $15(16,1)$ & $8(9,0)$ & $23(12,6)$ \\
\hline \multirow{3}{*}{$\begin{array}{l}\text { Breastmilk } \\
\text { substitute } \\
\text { foods } \\
\text { information } \\
\text { source }\end{array}$} & $\begin{array}{l}\text { Print and } \\
\text { electronic } \\
\text { media }\end{array}$ & $17(18,3)$ & $9(11,1)$ & $26(14,9)$ \\
\hline & $\begin{array}{l}\text { Health } \\
\text { workers }\end{array}$ & $54(58,1)$ & $21(25,9)$ & $75(43,1)$ \\
\hline & $\begin{array}{l}\text { Media and } \\
\text { health } \\
\text { workers } \\
\end{array}$ & $22(23,7)$ & $51(63,0)$ & $73(42,0)$ \\
\hline \multirow{3}{*}{$\begin{array}{l}\text { Breastmilk } \\
\text { substitute } \\
\text { foods } \\
\text { frequency }\end{array}$} & $\begin{array}{l}\text { Less than the } \\
\text { recommended } \\
\text { frequency }\end{array}$ & $57(61,3)$ & $36(40,4)$ & $93(51,1)$ \\
\hline & $\begin{array}{l}\text { More than the } \\
\text { recommended } \\
\text { frequency }\end{array}$ & $7(7,5)$ & $1(1,1)$ & $8(44,4)$ \\
\hline & $\begin{array}{l}\text { According to } \\
\text { the } \\
\text { recommended } \\
\text { frequency }\end{array}$ & $29(31,2)$ & $52(58,4)$ & $81(44,5)$ \\
\hline
\end{tabular}

Table 2 shows that most parents, amounting to 159 people $(87.4 \%)$, had received information about complementary foods. In addition, it was found that the source of information about complementary foods was mostly from health workers 75 people (43.1\%). Based on the frequency of complementary foods, most parents, 93 people $(51.1 \%)$, give complementary foods less than the recommended frequency.
Table 3. Results of Physical Examination in Children 12-24 Months in the Working Area of Sidorejo Health Center, $2019(\mathbf{n}=182)$

\begin{tabular}{|l|c|c|}
\hline \multirow{2}{*}{ Variable } & \multicolumn{2}{|c|}{$\mathbf{n}(\%)$ or average \pm SB } \\
\cline { 2 - 3 } & $\begin{array}{c}\text { Short Stature } \\
(\mathbf{n}=\mathbf{9 3})\end{array}$ & Normal (n=89) \\
\hline Body Length & $76,40 \pm 2,91$ & $79,2 \pm 4,23$ \\
\hline Weight & $9,70 \pm 1,50$ & $11,70 \pm 2,77$ \\
\hline
\end{tabular}

Table 3 stated that the average body length in the short stature children group was $76.40+2.91 \mathrm{~cm}$, while the average body length in the normal child group was $79.2+4.23 \mathrm{~cm}$. Meanwhile, the mean weight in the short stature children group was $9.70+1.50 \mathrm{~kg}$, while the mean weight in the normal children group was $11.70+2.77 \mathrm{~kg}$.

Table 4. Analysis of Child Age Associations when Obtaining complementary foods and Short Stature Events in Children aged 12-24 Months in the Work Area of Sidorejo Health Center, $2019(n=182)$

\begin{tabular}{|c|c|c|c|c|c|c|}
\hline \multirow[t]{2}{*}{$\begin{array}{l}\text { Variab } \\
\text { le }\end{array}$} & & \multicolumn{2}{|c|}{$\begin{array}{c}\text { n(\%) or average } \pm \\
\text { SB }\end{array}$} & & \multirow[t]{2}{*}{$\mathbf{p}^{*}$} & \multirow{2}{*}{$\begin{array}{c}\text { PR(9 } \\
5 \% \\
\text { CI) }\end{array}$} \\
\hline & & $\begin{array}{c}\text { Short } \\
\text { Statur } \\
e \\
(\mathrm{n}=93)\end{array}$ & $\begin{array}{c}\text { Normal } \\
(n=89)\end{array}$ & Total & & \\
\hline \multirow{2}{*}{$\begin{array}{l}\text { Breast } \\
\text { milk } \\
\text { substit } \\
\text { ute } \\
\text { foods } \\
\text { time }\end{array}$} & $\begin{array}{l}<6 \\
\text { months }\end{array}$ & $\begin{array}{c}53(76 \\
8)\end{array}$ & $16(23,2)$ & $\begin{array}{l}69(1 \\
00 \%)\end{array}$ & \multirow[t]{2}{*}{0,000} & \multirow{2}{*}{$\begin{array}{c}2,17 \\
(1,64 \\
- \\
2,87)\end{array}$} \\
\hline & $\begin{array}{l}\geq 6 \\
\text { months }\end{array}$ & $\begin{array}{c}40(35, \\
4)\end{array}$ & $73(64,6)$ & $\begin{array}{c}113( \\
100 \\
\%)\end{array}$ & & \\
\hline
\end{tabular}

* Corresponding to the frequencies analyzed with the Pearson Chi-square test ( $\alpha=0.05 ; 2$-tailed significance)

Table 4 is shown following the hypotheses in this study, an analysis of children's age associations when getting 
complementary foods, and the occurrence of short stature. The results show that there is a significant association between the age of the child when getting complementary food and the incidence of short stature in children aged 12-24 months $(p=0,000 ; p$ $<0.05$ ), so it can be concluded that there is a significant association between the age of the child when getting complementary foods and short stature incidence at the work area of the Puskesmas Sidorejo, Pare, Kediri. Analysis of the magnitude of risk shows that children who get complementary foods before six months have a risk of 2.170 times higher to experience short stature compared to those who get complementary foods after six months $(\mathrm{PR}=2.17 ; 95 \% \mathrm{CI}=1.64-2.87)$.

\section{DISCUSSION}

In the table of basic characteristics of the research subjects analyzed descriptively, we found that most maternal education in short stature children was junior high school education. Education level is one of the important aspects to improve the practice of giving complementary feeding. This is consistent with Mustamin et al. in 2015; the data obtained that a lower maternal education level will lead to children with short stature. ${ }^{13}$ Mothers who have a high level of education have better knowledge about nutrition for children. Theoretically, the availability of a mother's time in giving MP-ASI is closely related to work. This statement is different from the results obtained in this study which shows that the majority of mothers' work in short stature children and normal children is as a housewife. These results are in line with research conducted by Sulastri in 2012 . Sulastri found that maternal employment status did not play a role in short stature in children. Working mothers will have adequate income so that will affect the ability to fulfill family nutrition, especially nutrition for children. ${ }^{14}$

According to the demographic characteristics analyzed descriptively, the results of the study found that the percentage of preterm history in short stature children was slightly lower compared to normal children. If not balanced with the fulfillment of proper nutrition and nutrition, children born prematurely can experience short stature. This is different from a study conducted in Brazil which showed that the risk of short stature would increase in premature children. $^{15}$

The results obtained in this study indicate that the number of short stature children with a history of low birth weight was four times greater than children with normal body . The history of low birth weight can cause short stature in children because the digestive tract has not 
functioned properly. Food absorption becomes less efficient, and can experience electrolyte disturbances. Children who have a history of low birth weight but have a normal body length can be because the child has received adequate nutrition from pursuing growth per the child's age. Children who do not have low birth weight status but experience short stature can be caused by inadequate nutrition consumption in children.

According to demographic characteristics analyzed descriptively, the results of the study obtained data that in short stature and normal children tend to have little history of chronic disease. The endurance of each different child can cause the incident. The frequency of giving complementary foods to children in this study found a different percentage between short stature children and the normal group of children. The frequency of complementary foods that is less appropriate than recommended is more common in short stature children. Another thing with the frequency of complementary foods that is more than recommended is more common in normal children. Based on interviews conducted with mothers in this study, children who often consume snacks compared to main food will cause children to feel full quickly, so mothers will tend to reduce the frequency of eating in children.
When starting the administration of complementary foods, children aged 12-24 months are divided into two categories: before six months and six months. Children aged 12-24 months in the working area of the Sidorejo Puskesmas are more likely to receive complementary foods before six months of age, which likely lead to experiencing short stature when compared to normal children. The results of the data analysis test showed that children with complementary foods before six months had the risk of being short stature 2.17 times higher compared to children with complementary foods after six months $(\mathrm{PR}=2.17,95 \% \mathrm{CI}: 1$, 642.87). This result is supported by statistical tests using the Chi-square test, which obtained a P-value of $0,000(p<0.05)$. This shows a significant relationship between the child's age when getting complementary foods and the short stature incidence in the working area of the Puskesmas Sidorejo, Pare, Kediri. Theoretically, the right age for a child to get complementary foods is six months because the child's digestion is ready to receive food. Provision of complementary foods before six months can cause children to be malnourished, and children may experience growth retardation. 


\section{CONCLUSION}

Based on the results of research on the association of the age of children when getting complementary foods and the incidence of short stature in children 12-24 months in the work area of the Sidorejo Community Health Center, Pare Subdistrict, Kediri Regency, East Java on 182 respondents conducted from July to August 2019 can be concluded as follows:

1. The majority of mothers' education and occupation in short stature children were junior high school education and housewives.

2. Low birth weight history in short stature children is higher than in normal children.

3. There is a significant relationship between the provision of complementary foods and the incidence of short stature in children.

\section{ACKNOWLEDGEMENT}

1. Children and mothers who are in the working area of the Sidorejo Puskesmas UPTD, Pare District, Kediri Regency who are willing to become respondents.

2. Friends of the Faculty of Medicine, Widya Mandala Catholic University of Surabaya, class of 2016.

\section{REFERENCES}

1. Batubara JR, Bambang TA, Aman BP. Buku ajar endokrinologi anak. Edisi 3. Jakarta: Badan Penerbit Ikatan Dokter Anak Indonesia; 2018.hal.30-65.

2. WHO. Nutritional Landscape Information System (NLIS): Country profile indicators. 2010; Available from: https://www.who.int/nutrition/nlis/e $\mathrm{n} /$

3. Riskesdas. Riset Kesehatan Dasar (Riskesdas) 2013. Laporan Nasional 2013. 2013:209-15.

4. WHO. World health statistics data visualizations dashboard: child stunting [Internet]. 1 April 2019. Available from: https://www.who.int/gho/childmalnutrition/en/

5. Kementerian Kesehatan Republik Indonesia. Hasil riset kesehatan dasar Kementerian RI 2013. Proceedings, Annu Meet - Air Pollut Control Association 2013;

6. Kementerian Kesehatan RI. Situasi balita pendek. In: Pusat Data dan Informasi Kementerian Kesehatan RI, editor. Infodatin. 2016;1-4.

7. Riskesdas. Hasil utama Riskesdas 
2018. Kementerian Kesehatan Republik Indonesia. 2018;8-12.

8. Aramico B, Sudargo T, Susilo J. Hubungan sosial ekonomi, pola asuh, pola makan dengan stunting pada siswa sekolah dasar di Kecamatan Lut Tawar, Kabupaten Aceh Tengah. Jurnal Gizi dan Diet Indonesia (Indonesian Journal Nutrition Diet). 2013;1:121-30.

9. Sulistyoningsih H. Gizi untuk kesehatan ibu dan anak. 2nd ed. Yogyakarta: Graha ilmu; 2016.173175.

10. UNICEF. Pemberian makan bayi dan anak. Booklet Pesan Utama Paket Konseling. 2014;21-32.

11. Khasanah DP, Hadi H, Paramashanti BA. Waktu pemberian makanan pendamping ASI (MPASI) berhubungan dengan kejadian stunting anak usia 6-23 bulan di Kecamatan Sedayu. Jurnal Gizi dan Diet Indonesia (Indonesian Journal Nutrition Diet). 2016;2:105-11.

12. AL-Rahmad AH, Miko A, Hadi A. Kajian stunting pada anak balita ditinjau dari pemberian ASI ekslusif, MP-ASI, status imunisasi dan karakteristik keluarga di kota Banda Aceh. Jurnal Kesehatan Ilmu
Nasuwakes. 2013;6(2):169-84.

13. Mustamin, Akbar R, Budiawan. Tingkat pendidikan ibu dan pemberian ASI eksklusif dengan kejadian stunting pada balita di Provinsi Sulawesi Selatan. Jurnal Media Gizi Pangan. 2018;25(1):2530.

14. Sulastri D. Faktor determinan kejadian stunting pada anak usia sekolah di Kecamatan Lubuk Kilangan Kota Padang. Majalah Kedokteran Andalas. 2012;36(1):39-47.

15. Santos IS, Matijasevich A, Dominingues MR, Barros AJ, Victoria CG, Barros FC. Late preterm birth is a risk factor for growth faltering in early childhood: a cohort study. BMC Pediatri. 2009;9: 71-8. 